\title{
GMR
}

\section{Dietary zinc may attenuate heat-induced testicular oxidative stress in mice via up-regulation of $\mathrm{Cu}-\mathrm{Zn}$ SOD}

\author{
Y. Cao*, Y.S. Li*, Z.J. Li, F. Wang and C.M. Li \\ College of Animal Science and Technology, Nanjing Agricultural University, \\ Nanjing, China \\ *These authors contributed equally to this study. \\ Corresponding author: C.M. Li \\ E-mail: chunmeili@njau.edu.cn / lichunmei74@gmail.com
}

Genet. Mol. Res. 14 (4): 16616-16626 (2015)

Received June 22, 2015

Accepted September 28, 2015

Published December 11, 2015

DOI http://dx.doi.org/10.4238/2015.December.11.9

ABSTRACT. Zinc $(\mathrm{Zn})$ is important for male mammalian reproduction. In this study, we sought to clarify the role of $\mathrm{Zn}$ in heat-induced testicular damage in mice. Eighteen mice were divided into either control (con), heat (heat) and heat plus $\mathrm{Zn}(\mathrm{H}+\mathrm{Zn})$ treatment groups, and fed diets containing 60 (con and heat groups) or $300(\mathrm{H}+\mathrm{Zn}$ group) $\mathrm{mg} / \mathrm{kg} \mathrm{Zn}$ sulfate for one month. Mice in the con group were then maintained at $25^{\circ} \mathrm{C}$, while mice in heat and $\mathrm{H}+\mathrm{Zn}$ groups were exposed to $40^{\circ} \mathrm{C}$ for $2 \mathrm{~h}$ daily, for eight days. Mouse testes and serum from each animal were analyzed. Zinc levels in serum and testes were positively correlated to $\mathrm{Zn}$ feed concentrations. Mice in the heat group had higher testes index than those in the other two groups (7.22 \pm 0.75 , heat; $4.92 \pm 0.20$, con; $4.80 \pm 0.30 \mathrm{mg} / \mathrm{g}, \mathrm{H}+\mathrm{Zn} ; \mathrm{P}<$ 0.05). Testicular antioxidant status showed malondialdehyde levels in heat group mice were increased compared to control mice $(2.34 \pm 0.15$ versus $1.55 \pm 0.23 \mathrm{nmol} / \mathrm{mg}$ protein; $\mathrm{P}<0.05)$, and $\mathrm{Cu}-\mathrm{Zn}$ superoxide dismutase (SOD) level differed between heat and $H+Z n$ groups (14.04 \pm 0.74 versus $18.27 \pm 1.53 \mathrm{U} / \mathrm{mg}$ protein; $\mathrm{P}<0.05)$. Testicular $\mathrm{Cu}-\mathrm{Zn}$ SOD protein expression levels were significantly lower in the heat than in the control 
group $(0.30 \pm 0.11$ versus $1.22 \pm 0.13 ; P<0.05)$. These results suggest that dietary $\mathrm{Zn}$ may elevate the activity and protein concentration of $\mathrm{Cu}-\mathrm{Zn}$ SOD, to attenuate testicular oxidative stress induced by heat exposure.

Key words: Cu-Zn superoxide dismutase; Zinc; Heat exposure; Testes; Oxidative stress; Mouse

\section{INTRODUCTION}

Temperature is one of the most important physicochemical variables, and all physiological processes within an organism occur within a limited temperature range that differs depending on the molecular and cellular mechanisms associated with each particular process (Miranda et al., 2013). In mammalian species, cooler temperatures have been shown to be essential for maintenance of an optimal environment for spermatogenesis in the testes (Hughes and Acerini, 2008). Ambient temperatures above $40^{\circ} \mathrm{C}$ have been shown to result in scrotal temperatures above deep body temperature (Li et al., 2013). This has been found to be unfavorable for the formation of sperm, and results in abnormal spermatogenesis (Hughes and Acerini, 2008), induction of cryptorchidism and temporary or permanent infertility (Ikeda et al., 1999; Silanikove, 2000). In order to ensure the quality of sperm, therefore, it is important to prevent whole body heat stress.

Elevated body temperature may induce metabolic changes associated with the induction of oxidative stress (Lin et al., 2006). In mammals, heat stress may enhance the formation of reactive oxygen species (ROS) and induce cellular oxidative stress (Lin et al., 2006). Oxidative stress occurs following a disturbance in the balance between the production of ROS and antioxidant defense (Celino et al., 2011). Previous studies have revealed that spermatozoa are highly sensitive to ROS-induced damage (Aitken and Clarkson, 1987). Spermatozoa and seminal plasma contain a battery of ROS scavengers, including enzymes such as superoxide dismutase (SOD), catalase, and the glutathione peroxidase/reductase system (de Lamirande et al., 1997). The SODs were a family of enzymes that very efficiently catalyze the dismutation of superoxide radical anions, combined with excess peroxide to form water and oxygen. Superoxides have the capability to initiate free radical chain oxidations, inactivating specific enzymes and leading to the production of more powerful oxidants (Okado-Matsumoto and Fridovich, 2001). Nuclear factor erythroid2-related factor 2 (Nrf2) plays an important role in inhibiting oxidative stress; it is stabilized and transferred into the nucleus to promote the transcription of antioxidant genes, via binding to the antioxidant response element (ARE) sequence (Li et al., 2014).

Zinc $(\mathrm{Zn})$ is an essential bio-element with a fundamental role in a wide range of biochemical processes. It is a major component of various proteins and an important modulator of mammalian immunity, cellular proliferation, reproduction, and nervous system function, and provides defense against free radicals (Nowak et al., 2003; Ho, 2004). Zinc has also been found to be an indispensable element in reproduction and is required for the maintenance of germ cells; progression of spermatogenesis; and, regulation of sperm motility (Zhao et al., 2011). The effects of $\mathrm{Zn}$ deficiency are similar in most animal species and include dermatitis, alopecia, ocular lesions, testicular atrophy, growth retardation, and anorexia (Rossi et al., 2001). Zinc deficiency in male reproduction results in gonad dysfunction, decreased testicular weight, and seminiferous tubule shrinkage (Bedwal and Bahuguna, 1994). Zinc supplementation may inhibit ROS generation, and enhance the activity of antioxidant pathways (Zhou et al., 2005). Furthermore, Zn participates in 
cell membrane stabilization, metallothionein (Mt) synthesis and Cu-Zn SOD structure (Jemai et al., 2007), and, when added to the diet of healthy humans, may reduce concentrations of oxidative stress (Prasad et al., 2007). It remains unclear, however, whether $\mathrm{Zn}$ protects the testis from heat-induced oxidative damage. In the present study, therefore, we investigated the effects of $\mathrm{Zn}$ supplementation on the testicular damage of heat-induced mice.

\section{MATERIAL AND METHODS}

\section{Animals}

Male adult Institute of Cancer Research (ICR) mice, 8weeks old, were purchased from Nanjing Qinglongshan Experimental Animal Center (China, Jiangsu). Mice were provided with food and water ad libitum and were maintained on a $12 \mathrm{~h}$ light-dark cycle under controlled temperature $\left(25^{\circ} \mathrm{C}\right)$ and relative humidity $(\mathrm{RH})(50 \pm 5 \%)$. Mice were allowed to acclimatize to the experimental setting for one week before the commencement of the study. Procedures involving live animals were approved by the Institutional Animal Care and Use Committee of Nanjing Agricultural University.

\section{Experimental design}

Eighteen mice were divided into three groups (each $N=6$ ). Prior to heat exposure, the three groups were fed a diet with $\mathrm{Zn}$ supplemented in the form of $\mathrm{ZnSO}_{4}$ at $60 \mathrm{mg} / \mathrm{kg}$ body weight for animals in the con and heat groups, and $300 \mathrm{mg} / \mathrm{kg}$ for mice in the $\mathrm{H}+\mathrm{Zn}$ group. Mice were maintained on this diet for one month. The higher dose was selected on the basis of a previous study, in which $300 \mathrm{mg} / \mathrm{kg} \mathrm{Zn}$ added to the diet induced minimal adverse effects associated with high dietary $\mathrm{Zn}$ (Simon and Taylor, 2001). After one month on the diet, mice in the heat and $\mathrm{H}+\mathrm{Zn}$ groups were exposed to whole body heat treatment.

To investigate the effect of whole body heat treatment on testicular oxidative stress and antioxidant system, mice in the treatment groups were exposed to an ambient temperature of $40^{\circ} \mathrm{C}$. Mice in the con group were housed under controlled conditions $\left(25^{\circ} \mathrm{C}, 50 \pm 5 \% \mathrm{RH}\right)$ throughout the heat treatment period. Mice in heat group were housed under control group conditions, but additionally subjected to $40^{\circ} \mathrm{C}$ and $50 \pm 5 \% \mathrm{RH}$ between 12 and 2 p.m. daily, for eight consecutive days during heat treatment period. The whole body heat temperature of $40^{\circ} \mathrm{C}$ for $2 \mathrm{~h}$ was selected on the basis of previous reports of total recovery after heat treatment and feasible parameters for a chronic heat model in mice (Rossi et al., 2001; Li et al., 2013). Following heat treatment each day, feed weight (as a measure of feed intake) and body weights were of all mice were recorded.

\section{Sample collection}

After eight days of heat treatment, mice were weighed. Immediately after mice anesthetized with ether, blood samples were collected and centrifuged at $3500 \mathrm{~g}$ for $10 \mathrm{~min}$. Isolated sera were stored at $-80^{\circ} \mathrm{C}$ prior to further processing. Testes were collected, immediately placed on ice and dissected. Upon further processing, testes were weighed and the left testis returned to $-80^{\circ} \mathrm{C}$ for subsequent biochemical measure and western blot analysis. The right testis was immersed in $4 \%$ paraformaldehyde solution for histological analysis. 


\section{Measurement of $\mathrm{Zn}$ levels in testis and serum}

Zinc levels in testes were measured using an atomic absorption spectrometer with airacetylene flame, following tissue digestion in nitric acid (Zhao et al., 2011). Using this assay, total $\mathrm{Zn}$ in tissues, including free and protein-bound forms, were measured and expressed per gram wet tissue (Cai et al., 2002). Tissue samples (approximately $0.5 \mathrm{~g}$ )and serum (100 $\mu \mathrm{L}$ ) were incubated overnight in nitric acid $(10 \mathrm{~mL})$ at room temperature and then heated to $95^{\circ} \mathrm{C}$ for $1 \mathrm{~h}$, $150^{\circ} \mathrm{C}$ for $1 \mathrm{~h}$, and $230^{\circ} \mathrm{C}$ for $30 \mathrm{~min}$ to facilitate digestion. When liquid temperature decreased to room temperature, then ultrapure water was added to dilute the sample (final volume $25 \mathrm{~mL}$ ). The resulting clear liquid was used to determine $\mathrm{Zn}$ concentrations by inductively coupled plasm optical emission spectrometry (Optima 2100DV, PerkinEImer, Waltham, MA, USA).

\section{Analysis of the testicular oxidative stress parameters}

Testes samples were assessed to determine parameters of oxidative stress that included levels of enzymatic antioxidants $\mathrm{Cu}-\mathrm{Zn}$ SOD, glutathione peroxidase (GPX), malonaldehyde (MDA), and $\gamma$-glutamyl cysteine synthetase ( $\gamma$-GCS). Frozen testicular tissue was homogenized in ice-cold $\mathrm{NaCl}$ solution, then centrifuged at $1700 \mathrm{~g}$ for $15 \mathrm{~min}$ at $4^{\circ} \mathrm{C}$. Enzyme activities in sample supernatant were then analyzed using a commercial assay kit (Jiancheng Bioengineering Institute, Nanjing, China) according to the manufacturer instructions.

\section{Histological evaluation of testicular tissues}

Testes were fixed in 4\% paraformaldehyde and embedded in paraffin. Then, $6-\mu \mathrm{m}$ sections were affixed to slides, stained with hematoxylin-eosin (HE) and assessed for morphologic changes, using an optical microscope (BX 51, Olympus, Tokyo, Japan).

\section{Western blot analysis of testicular protein expression}

Protein was extracted from the nucleus to test the Nrf2 level in nucleus, and whole-cell levels of Cu-Zn SOD were assessed. Testicular tissues were homogenized and fractionated on $10 \%$ SDS-PAGE (w/v) gels, and proteins were transferred to a nitrocellulose membrane. Membranes were blocked in $5 \%$ non-fat dried milk (w/v) for $1 \mathrm{~h}$, and incubated overnight at $4^{\circ} \mathrm{C}$ with anti-Cu-Zn SOD (1:1000) and anti-Nrf2 (1:500) antibodies (both Abcam, MA, USA). After unbound antibodies were removed with Tris-buffered saline $(\mathrm{pH} 7.2)$ containing $0.05 \%$ Tween 20 , membranes were incubated at room temperature with secondary antibody for $2 \mathrm{~h}$. Antigenantibody complexes were visualized with an enhanced chemiluminiscence kit (Thermo Scientific, New York, USA). Quantitative densitometry was performed on identified bands using a computerbased measurement system (Zhao et al., 2011). Histon3 and $\beta$-actin were employed as loading controls for the nuclear and cytoplasmic protein, respectively.

\section{Statistical analysis}

Data were calculated as group means \pm standard errors of the mean (SEM). Statistical analysis was performed using GraphPad Prism Version 5.0 software program (GraphPad Software, 
San Diego, CA, USA). Data were analyzed using one-way analysis of variance (ANOVA) with Tukey's multiple comparison tests. Differences were considered to be statistically significant when $P<0.05$.

\section{RESULTS}

\section{Zn levels in testes and serum}

Zinc levels in testes and sera were significantly increased in the $300 \mathrm{mg} / \mathrm{kg}$ dietary $\mathrm{Zn}$ groups, compared with the con group $(P<0.01$; Figure 1).

\section{A}

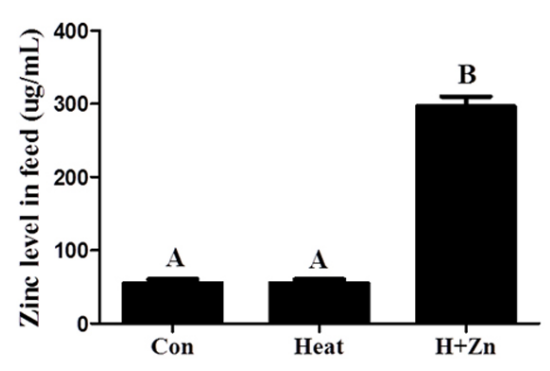

B

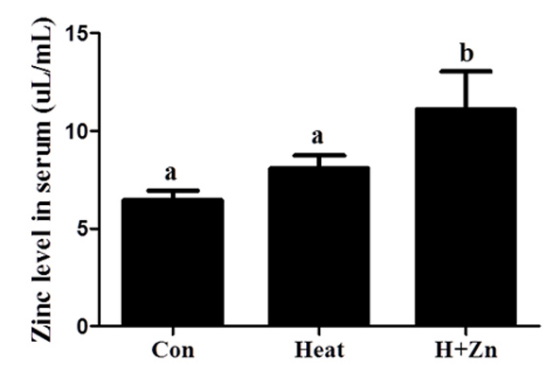

C

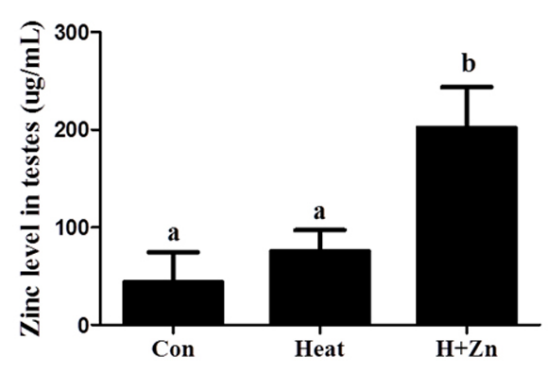

Figure 1. Zinc level in feed, serum, and testis of experimental groups. Zinc levels in feed (A), serum (B) and testis (C). Bars represent the mean \pm SEM $(N=6)$. Means in the same rows with different lowercase letters are significantly different $(P<0.05)$, and uppercase letters indicate significant differences $(P<0.01)$. 


\section{Feed intake and testes index}

Mean body weight gain was measured for the three groups and compared every day following heat treatment. Weight gain did not differ between all groups $(P>0.05)$, but $H+Z n$ mice showed a trend of increased weight, compared to the other two groups (Table 1). Average daily feed intake in mice in the heat group was reduced compared to the control, and significantly reduced compared to the $\mathrm{H}+\mathrm{Zn}$ group $(\mathrm{P}<0.05)$ (Table 1$)$. Testes indexes were obtained by dividing testes weight by body weight; this measure was significantly higher in the heat group compared to the other two groups $(P<0.05)$, and was reduced in the $H+Z n$ group $(P<0.01$; Table 1$)$.

Table 1. Effect of $Z n$ supplementation on body and testes weight, and average daily feed intake of heat-treated mice.

\begin{tabular}{lrrr}
\hline & & Treatment group \\
\cline { 2 - 4 } & \multicolumn{1}{c}{ Con } & Heat & $\mathrm{H}+\mathrm{Zn}$ \\
\hline Body weight $(\mathrm{g})$ & $43.15 \pm 1.16$ & $38.19 \pm 0.91$ & $37.02 \pm 1.46$ \\
Average daily weight gain $(\mathrm{g})$ & $0.13 \pm 0.12$ & $0.10 \pm 0.15$ & $0.23 \pm 0.12$ \\
Average daily feed intake $(\mathrm{g})$ & $4.29 \pm 0.21^{\mathrm{ab}}$ & $3.81 \pm 0.18^{\mathrm{a}}$ & $4.56 \pm 0.14^{\mathrm{b}}$ \\
Testes weight $(\mathrm{mg})$ & $211.43 \pm 0.83^{\mathrm{AB}}$ & $275.73 \pm 0.61^{\mathrm{A}}$ & $177.70 \pm 0.92^{\mathrm{B}}$ \\
Testes weight/body weight $(\mathrm{mg} / \mathrm{g})$ & $4.90 \pm 0.20^{\mathrm{a}}$ & $7.22 \pm 0.75^{\mathrm{Ab}}$ & $4.80 \pm 0.30^{\mathrm{B}}$ \\
\hline
\end{tabular}

Values are expressed as group mean \pm SEM $(\mathrm{N}=6)$. Different lowercase letters indicate significant differences between groups $(P<0.05)$; uppercase letters indicate significant differences $(P<0.01)$.

\section{Oxidative stress parameter in the testes}

Levels of MDA were higher in mice in the heat group, compared to those in the other two groups $(\mathrm{P}<0.05$; Figure $2 \mathrm{~A})$. The $\mathrm{H}+\mathrm{Zn}$ group showed increased $\mathrm{Cu}-\mathrm{Zn}$ SOD activity in the testes, but decreased $\gamma$-GCS activity, compared to the heat group (both $P<0.05$; Figure $2 B$ and $D$ ). There was no difference in GPX activity between the groups $(P>0.05$; Figure $2 C)$.
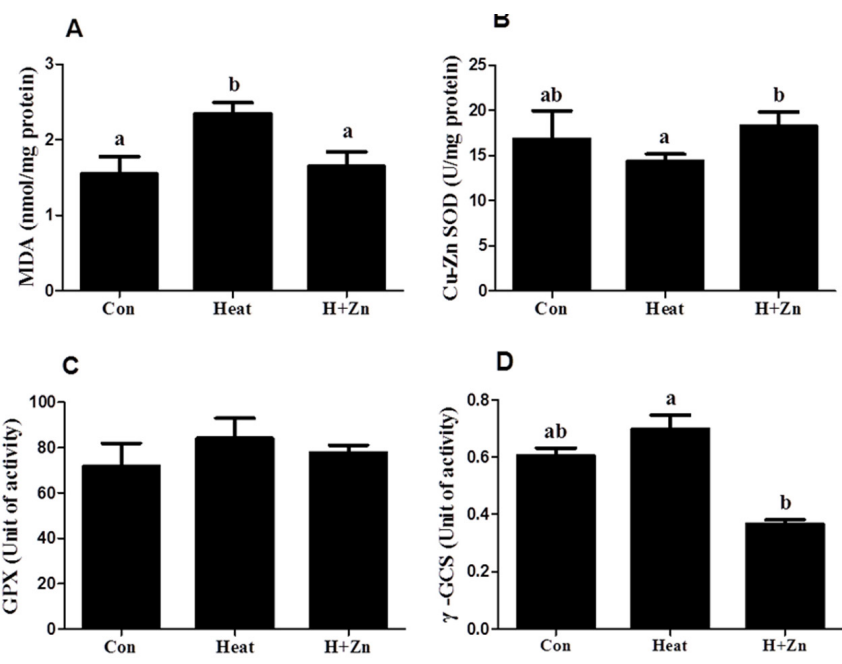

Figure 2. Effects of zinc on the oxidative stress parameters in the testes of the heat-treated mice. A. Malondialdehyde, MDA; B. Cu-Zn superoxide dismutase, Cu-Zn SOD; C. glutathione peroxidase, GPX and D. y-glutamyl cysteine synthetase, $\gamma$-GCS. Bars represent the mean \pm SEM $(N=6)$. Different lowercase letters indicate significant differences between groups $(P<0.05)$. 


\section{Histological evaluation of testes}

There were obviously different degrees of pathological changes in the testes of mice from the different groups. For the con group, integrated seminiferous ducts and normal spermatogenic cells were observed (Figure $3 \mathrm{~A}$ ). There were obvious condensation of germ cell nuclei and lost germ cells in the seminiferous epithelium, suggesting that germ cells were undergoing apoptosis (Figure 3B). Testicular structure was relatively intact in mice in the $\mathrm{H}+\mathrm{Zn}$ group as compared to the heat group. However, multinucleated giant cells and single germ cells were still clearly observed in testicular lumen, implying that germ cells were undergoing necrosis (Figure 3C).
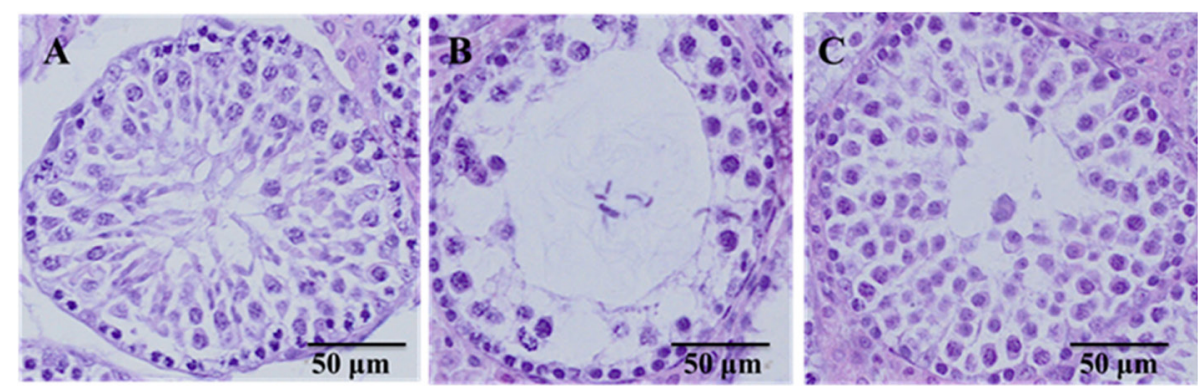

Figure 3. Hematoxylin-eosin staining of mouse testes. Control (con; A) and heat (heat; B) and heat plus zinc group $(\mathrm{H}+\mathrm{Zn} ; \mathrm{C})$ treatment groups. Bar $=50 \mu \mathrm{m}$. For each experimental group, representative images from five mice are shown.

\section{Testicular expression of Cu-Zn SOD and Nrf2}

A band for $\mathrm{Cu}-\mathrm{Zn}$ SOD protein was detected for all groups, that was obviously shallower in the heat group than the others (Figure 4). The Cu-Zn SOD protein level in the heat group was significant lower than the other two groups $(P<0.05)$. There was no significant difference in $\mathrm{Cu}-\mathrm{Zn}$ SOD protein level between the con group and the $\mathrm{H}+\mathrm{Zn}$ group.

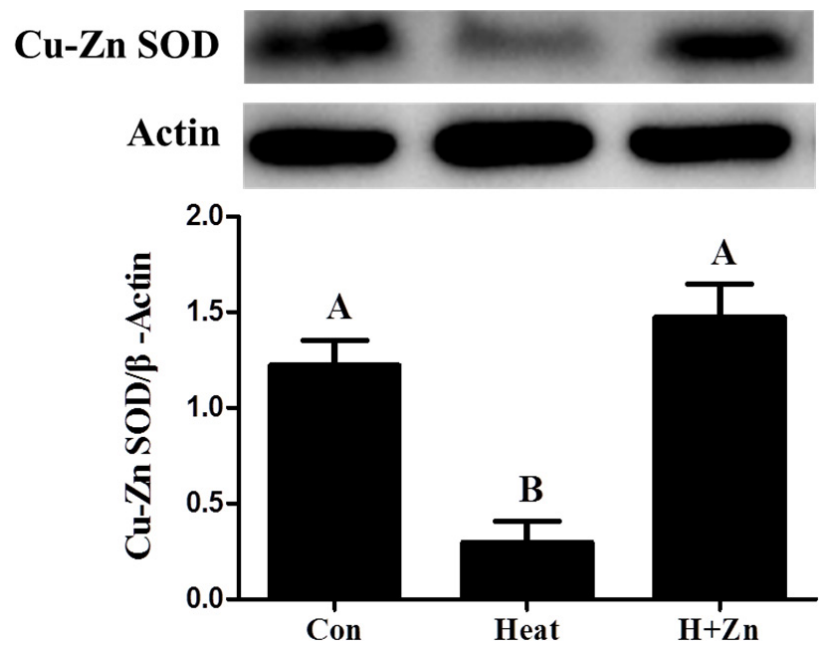

Figure 4. Cu-Zn SOD protein change in the testes of heat-treated mice. Western blotting. Different uppercase letters indicate significant differences between groups $(P<0.01)$. 
We investigated whether changes occurred in the intra-nuclear levels of protein Nrf2, which is a key regulator in the cellular defense system against oxidative stress (Shen et al., 2014). Levels of Nrf2 expression in the heat group were increased compared to the control group, while levels of intra-nuclear Nrf2 in the $\mathrm{H}+\mathrm{Zn}$ group were lower, compared to the heat group $(\mathrm{P}<0.05$; Figure 5). This finding suggests that heat treatment promotes Nrf2 expression in the nucleus, and that increased dietary $\mathrm{Zn}$ could decrease this state.

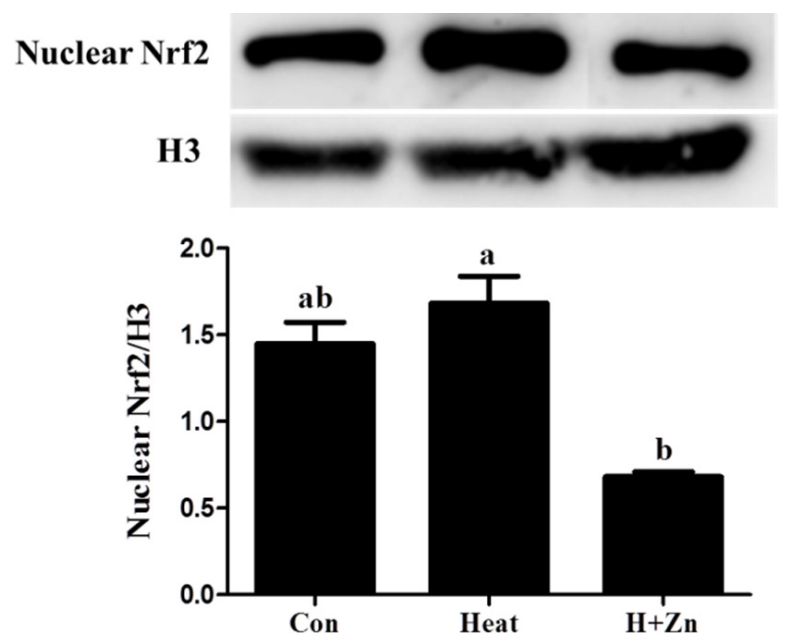

Figure 5. Nrf2 protein change in the testes of heat-treated mice. Western blotting. Different lowercase letters indicate significant differences between groups $(P<0.05)$.

\section{DISCUSSION}

In the present study, heat exposure caused testicular oxidative stress in mice. We observed that dietary $\mathrm{Zn}$ supplementation up-regulated testicular $\mathrm{Cu}-\mathrm{Zn}$ SOD levels, which may remit this oxidative damage to some degree.

It has been previously demonstrated that low $\mathrm{Zn}$ levels in diets result in reduced levels of $\mathrm{Zn}$ in serum, urine, sweat and hair (Paknahad et al., 2007), indicating that dietary $\mathrm{Zn}$ accumulates in the tissues of animals. The uptake and accumulation of $\mathrm{Zn}$ has also been shown to result in mitochondrial release of cytochrome $\mathrm{c}$, which initiates the caspase cascade that leads to apoptosis (Feng et al., 2008); it has therefore been suggested that dietary Zn may prevent cellular apoptosis. In the current study, we observed a positive correlation between $\mathrm{Zn}$ levels in testes and sera, and levels in feed, indicating that dietary $\mathrm{Zn}$ accumulates in mouse tissues and serum.

Previously studies have indicated that high ambient temperatures lead to slow growth, feed intake, reproductive performance and decreased weight gain in animals (Spencer et al., 2003; Song et al., 2012). Supplemental $\mathrm{Zn}$ in the diet of nursery pigs has been shown to improve pig growth performance (Case and Carlson, 2002). Japanese quail fed with dietary Zn showed an attenuated effect on the heat stress-induced poor egg production (Sahin and Kucuk, 2003). In the current study, average daily intake was reduced in the heat group, compared to control and $\mathrm{H}+\mathrm{Zn}$ groups, in accordance with previous findings. Research has demonstrated that summer heat stress may lead to a small increase in testicular growth in ram lambs (Rasooli et al., 2010). Such an effect was also observed in our study, in which an improved testes index was seen in the 
heat group, which could be decreased by $\mathrm{Zn}$ supplement; this indicates that heat treatment may cause testicular swelling that can be alleviated by supplementation with $\mathrm{Zn}$ in feed. Moreover, $\mathrm{Zn}$ supplementation appeared to reduce the incidence of heat-induced morphological abnormalities, such as apoptosis of Leydig cells. This suggests that supplemental dietary $\mathrm{Zn}$ attenuated heatinduced damage in the testes.

Oxidative stress is caused by numerous factors including elevated temperature, and has been shown to be widely involved in apoptosis and germ cell death, and in the pathophysiology of male infertility (Paul et al., 2009; Shiraishi et al., 2010). Heat treatment induces oxidative stress in testes, mainly through mitochondria-derived ROS and lipid peroxidation of the cellular membrane (Li et al., 2013). Increased oxidative stress is characterized by elevated MDA levels, considered to be an indicator of oxidative stress (Li et al., 2013). In our study, we demonstrated that chronic heat stress increased testicular MDA levels in mice, and $Z n$ supplemented in feed decreased the effect of heat on MDA levels. This suggests that dietary $\mathrm{Zn}$ may attenuate testicular oxidative stress in heat-exposed mice.

As a primary antioxidant enzyme, SOD plays an important role in testicular tissues. High levels of $\mathrm{Cu}-\mathrm{Zn}$ SOD and $\mathrm{Zn}$ increase spermatogonia resistance to $\mathrm{ROS}$ and reduce oxidative stress (Ishii et al., 2005). Activity levels of the enzyme Cu-Zn SOD have been shown to be high in testis of eels (Celino et al., 2011). Furthermore, decreased protein levels of Cu-Zn SOD may increase ROS levels, resulting in lipid peroxidation in the liver, brain, and testes, as well as other deleterious effects on cell structure. Over-expression of Cu-Zn SOD has been shown to result in extended life span (Koksal et al., 2000; Ahlemeyer et al., 2001; Orr and Sohal, 2003; Celino et al., 2011). At the same time, Zn (II) could lead to increased Cu-Zn SOD activity (Mei et al., 2013). In the current study, the antioxidant index and protein levels of $\mathrm{Cu}$-Zn SOD in testes were significantly reduced in heat stressed mice, while mice that were heat-treated but received supplemental dietary $\mathrm{Zn}$ had levels that were comparable to control mice, suggesting that dietary $\mathrm{Zn}$ improves $\mathrm{Cu}-\mathrm{Zn}$ SOD levels to remit heat-induced oxidative damage in the testes of mice.

$\mathrm{Nrf2}$ is a key regulator in the cellular defense system against oxidative stress (Shen et al., 2014). The presence of excess ROS and Zn could stimulate the Nrf2-antioxidative signaling pathway, thus prevent oxidative stress (Kobayashi et al., 2004; Li et al., 2014). $\gamma$-GCS has been found to be a rate-limiting enzyme involved in the synthesis of glutathione that is up-regulated by Nrf2 levels (Jeyapaul and Jaiswal, 2000). In the current study, we observed that there were obvious decrease in Nrf2 protein level and $\gamma$-GCS activity in testis in the $\mathrm{H}+\mathrm{Zn}$ group. Considering that there is no significant difference in MDA level between the con and the $\mathrm{H}+\mathrm{Zn}$ group, pretreatment of dietary $\mathrm{Zn}$ could maintain the oxidation-reduction equilibrium, and therefore the Nrf2-antioxidative signaling pathway was stabilized under the basal line level in the mouse testis during heat stress.

In summary, we demonstrated that dietary $\mathrm{Zn}$ pretreatment for one month could ameliorate heat-induced testicular injury in mice. Dietary Zn supplementation increased the Cu-Zn SOD level, decreased the MDA level, and maintained the Nrf2 protein expression under low level in the testes of mice, implying that it might via improving the Cu-Zn SOD level to resist heat-induced oxidative stress when mice were exposed to high ambient temperature.

\section{ACKNOWLEDGMENTS}

Research supported by the National Natural Science Foundation of China (grant \#31272485 and \#31402116), the QingLan Project, and the National "Twelfth-Five Year" Research Program of China (grant \#2012BAD39B02). 


\section{REFERENCES}

Ahlemeyer B, Bauerbach E, Plath M, Steuber M, et al. (2001). Retinoic acid reduces apoptosis and oxidative stress by preservation of SOD protein level. Free Radic. Biol. Med. 30: 1067-1077.

Aitken RJ and Clarkson JS (1987). Cellular basis of defective sperm function and its association with the genesis of reactive oxygen species by human spermatozoa. J. Reprod. Fertil. 81: 459-469.

Bedwal RS and Bahuguna A (1994). Zinc, copper and selenium in reproduction. Experientia 50: 626-640.

Cai L, Chen S, Evans T, Cherian MG, et al. (2002). Endothelin-1-mediated alteration of metallothionein and trace metals in the liver and kidneys of chronically diabetic rats. Int. J. Exp. Diabetes Res. 3: 193-198.

Case CL and Carlson MS (2002). Effect of feeding organic and inorganic sources of additional zinc on growth performance and zinc balance in nursery pigs. J. Anim. Sci. 80: 1917-1924.

Celino FT, Yamaguchi S, Miura C, Ohta T, et al. (2011). Tolerance of spermatogonia to oxidative stress is due to high levels of Zn and Cu/Zn superoxide dismutase. PloS One 6: e16938.

de Lamirande E, Jiang H, Zini A, Kodama H, et al. (1997). Reactive oxygen species and sperm physiology. Rev. Reprod. 2: 48-54.

Feng P, Li T, Guan Z, Franklin RB, et al. (2008). The involvement of Bax in zinc-induced mitochondrial apoptogenesis in malignant prostate cells. Mol. Cancer 7: 25 .

Ho E (2004). Zinc deficiency, DNA damage and cancer risk. J. Nutr. Biochem. 15: 572-578.

Hughes IA and Acerini CL (2008). Factors controlling testis descent. Eur. J. Endocrinol. 159 (Suppl 1): S75-S82.

Ikeda M, Kodama H, Fukuda J, Shimizu Y, et al. (1999). Role of radical oxygen species in rat testicular germ cell apoptosis induced by heat stress. Biol. Reprod. 61: 393-399.

Ishii T, Matsuki S, luch, Y, Okada F, et al. (2005). Accelerated impairment of spermatogenic cells in SOD1-knockout mice under heat stress. Free Radic. Res. 39: 697-705.

Jemai H, Messaoudi I, Chaouch A and Kerkeni A (2007). Protective effect of zinc supplementation on blood antioxidant defense system in rats exposed to cadmium. J. Trace Elem. Med. Biol. 21: 269-273.

Jeyapaul J and Jaiswal AK (2000). Nrf2 and c-Jun regulation of antioxidant response element (ARE)-mediated expression and induction of gamma-glutamylcysteine synthetase heavy subunit gene. Biochem. Pharmacol. 59: 1433-1439.

Kobayashi A, Kang MI, Okawa H, Ohtsuji M, et al. (2004). Oxidative stress sensor Keap1 functions as an adaptor for Cul3based E3 ligase to regulate proteasomal degradation of Nrf2. Mol. Cell Biol. 24: 7130-7139.

Koksal IT, Tefekli A, Usta M, Erol H, et al. (2000). The role of reactive oxygen species in testicular dysfunction associated with varicocele. BJU Int. 86: 549-552.

Li Y, Huang Y, Piao Y, Nagaoka K, et al. (2013). Protective effects of nuclear factor erythroid 2-related factor 2 on whole body heat stress-induced oxidative damage in the mouse testis. Reprod. Biol. Endocrinol. 11: 23.

Li Y, Cao Y, Wang F and Li C (2014). Scrotal heat induced the Nrf2-driven antioxidant response during oxidative stress and apoptosis in the mouse testis. Acta Histochem. 116: 883-890.

Lin H, Decuypere E and Buyse J (2006). Acute heat stress induces oxidative stress in broiler chickens. Comp. Biochem. Physiol. A 144: 11-17.

Mei XT, Xu DH, Xu SK, Zheng YP, et al. (2013). Zinc (II)-curcumin accelerates the healing of acetic acid-induced chronic gastric ulcers in rats by decreasing oxidative stress and downregulation of matrix metalloproteinase-9. Food Chem. Toxicol. 60: 448-454.

Miranda LA, Chalde T, Elisio M and Strussmann CA (2013). Effects of global warming on fish reproductive endocrine axis, with special emphasis in pejerrey Odontesthes bonariensis. Gen. Comp. Endocrinol. 192: 45-54.

Nowak G, Siwek M, Dudek D, Zieba A, et al. (2003). Effect of zinc supplementation on antidepressant therapy in unipolar depression: a preliminary placebo-controlled study. Pol. J. Pharmacol. 55: 1143-1147.

Okado-Matsumoto A and Fridovich I (2001). Subcellular distribution of superoxide dismutases (SOD) in rat liver: $\mathrm{Cu}, \mathrm{Zn}-\mathrm{SOD}$ in mitochondria. J. Biol. Chem. 276: 38388-38393.

Orr WC and Sohal RS (2003). Does overexpression of Cu,Zn-SOD extend life span in Drosophila melanogaster? Exp. Gerontol. 38: $227-230$.

Paknahad Z, Mahdavi R, Mahboob S, Ghaemmaghami SJ, et al. (2007). Iron and zinc nutritional and biochemical status and their relationship among child bearing women in Mar and province. Pak. J. Nutr. 6: 672-675.

Paul C, Teng S and Saunders PT (2009). A single, mild, transient scrotal heat stress causes hypoxia and oxidative stress in mouse testes, which induces germ cell death. Biol. Reprod. 80: 913-919.

Prasad AS, Beck FW, Bao B, Fitzgerald JT, et al. (2007). Zinc supplementation decreases incidence of infections in the elderly: effect of zinc on generation of cytokines and oxidative stress. Am. J. Clin. Nutr. 85: 837-844.

Rasooli A, TahaJalali M, Nouri M, Mohammadian B, et al. (2010). Effects of chronic heat stress on testicular structures, serum testosterone and cortisol concentrations in developing lambs. Anim. Reprod. Sci. 117: 55-59. 
Rossi L, Migliaccio S, Corsi A, Marzia M, et al. (2001). Reduced growth and skeletal changes in zinc-deficient growing rats are due to impaired growth plate activity and inanition. J. Nutr. 131: 1142-1146.

Sahin K and Kucuk O (2003). Zinc supplementation alleviates heat stress in laying Japanese quail. J. Nutr. 133: 2808-2811.

Shen B, Wang W, Ma L, Wang S, et al. (2014). Sulforaphane restores oxidative stress induced by di-N-butylphthalate in testicular Leydig cells with low basal reactive oxygen species levels. Urology 84: 850-856.

Shiraishi K, Takihara H and Matsuyama H (2010). Elevated scrotal temperature, but not varicocele grade, reflects testicular oxidative stress-mediated apoptosis. World J. Urol. 28: 359-364.

Silanikove N (2000). Effects of heat stress on the welfare of extensively managed domestic ruminants. Livest. Prod. Sci. 67: 1-18.

Simon SF and Taylor CG (2001). Dietary zinc supplementation attenuates hyperglycemia in db/db mice. Exp. Biol. Med. 226: 43-51.

Song Z, Liu L, Sheikhahmadi A, Jiao H, et al. (2012). Effect of heat exposure on gene expression of feed intake regulatory peptides in laying hens. J. Biomed. Biotechnol. 2012: 484869.

Spencer JD, Boyd RD, Cabrera R and Allee GL (2003). Early weaning to reduce tissue mobilization in lactating sows and milk supplementation to enhance pig weaning weight during extreme heat stress. J. Anim. Sci. 81: 2041-2052.

Zhao Y, Tan Y, Dai J, Li B, et al. (2011). Exacerbation of diabetes-induced testicular apoptosis by zinc deficiency is most likely associated with oxidative stress, p38 MAPK activation, and p53 activation in mice. Toxicol. Lett. 200: 100-106.

Zhou Z, Wang L, Song Z, Saari JT, et al. (2005). Zinc supplementation prevents alcoholic liver injury in mice through attenuation of oxidative stress. Am. J. Pathol. 166: 1681-1690. 